\title{
Effect of the addition of glasses as sintering aids on microstructure and properties of nanoalumina
}

\author{
Efeito da adição de compostos vítreos \\ como auxiliares de sinterização na \\ microestrutura e propriedades da \\ nanoalumina
}

\author{
Larissa Bezerra da Silva ${ }^{1}$, Diego Blaese ${ }^{2}$, \\ Ana Paula da Silva Peres ${ }^{1}$, Antonio Carlos Silva da Costa ${ }^{1}$, \\ Wilson Acchar ${ }^{1}$
}

\footnotetext{
${ }^{1}$ Graduate Program on Materials Science and Engineering (PPGCEM), Federal University of Rio Grande do Norte (UFRN), CEP: 59078-900, Natal, RN, Brazil.

e-mail: larissabezerramat@gmail.com, anapsperes@gmail.com, acarlossc@gmail.com,wacchar@gmail.com

${ }^{2}$ Institute of Advanced Ceramics, Hamburg University of Technology (TUHH), D-21071, Hamburg, Hamburg, Germany. e-mail: diegoblaese@gmail.com
}

\begin{abstract}
Alumina-Glass compositions were prepared to evaluate the effect of glass as sintering aids. The composites showed densification below $1100^{\circ} \mathrm{C}$. The highest density values $(\sim 95 \%)$ were obtained for compositions based respectively on borosilicate (G2 and G3) and soda lime glasses (G4), all containing Na in the precursor powder. Samples G1 (K-based) and G5 (no K or Na in the precursor glass powder) presented irregular morphology with the presence of intergranular porosity. The composition G2, G3, and G4 presented uniform morphology corresponding to higher densification.
\end{abstract}

Keywords: Glass, Alumina, Sintering Aid, Densification.

\section{RESUMO}

As composições de alumina-reforço foram preparadas para avaliar o efeito da fase vítrea como auxiliar de sinterização. Os compósitos apresentaram densificação abaixo de $1100{ }^{\circ} \mathrm{C}$. Os maiores valores de densidade $(\sim 95 \%)$ foram obtidos para composições baseadas respectivamente em vidros de borossilicato (G2 e G3) e soda e cal (G4), todos contendo Na no pó precursor. As amostras G1 (à base de K) e G5 (sem K ou Na no pó do vidro precursor) apresentaram morfologia irregular com presença de porosidade intergranular. As composições G2, G3 e G4 apresentaram morfologia uniforme, correspondendo a uma maior densificação.

Palavras-chave: Vidro, Alumina, Auxiliar de sinterização, Densificação.

\section{INTRODUCTION}

In recent years, many efforts have been devoted to improving the thermal, chemical and mechanical behavior ceramic materials and composites, exploring different strategies, such as new compositions including sintering aids that make up the ceramic matrix [1], design of tailored microstructures for the production of ceramic laminates [2], the use of nanosized secondary phases [3,4].

Alumina-based ceramics are widely used materials in many industrial applications. These materials have exceptional combined properties and are often used in advanced structural ceramics. Alumina compounds with secondary oxides phases are often manufactured to improve some properties, such as corrosion 
and oxidation resistance, hardness and mechanical stability. Particularly, the formation of a glassy phase during sintering at high temperatures may aid the densification of alumina ceramics [5].

Several studies have been carried out using a mixture of glass and alumina in different proportions for enhancing processing conditions and final properties of a single matrix or composites based on alumina [6-9]. The association of aluminate a glass forming system generally contributes to the reduction of sintering temperatures [10]. If a suitable glass composition is selected, the composite may have controlled closed porosity and properties, such as dielectric constant, thermal expansion and tightness required for highperformance microelectronic substrates [11].

Sintering aids are intentional chemical modifiers that act to promote greater particle contact and allow reactions in the pores of the constituent oxides, thus reducing the energy required for the diffusive and viscous flow processes to occur improving densification of the material [12]. These aids might be combinations of one or more oxides which are added as well to control grain growth, in addition to improving densification by forming a liquid phase [13,14].

In this context, the present study aims to obtain alumina ceramics using glass compositions as sintering aids to improve physical and microstructural features.

\section{MATERIALS AND METTHODS}

The compositions chosen in this work were based on the research done by $[6,7,8,9]$ as presented in Table 1 .

Table 1: Alumina-glass compositions used in this work.

\begin{tabular}{|c|c|c|c|c|c|}
\hline Matrix & \multicolumn{5}{|c|}{95 wt. $\% \mathrm{Al}_{2} \mathrm{O}_{3}$} \\
\hline Filler & \multicolumn{5}{|c|}{5 wt. \% glass } \\
\hline Sample & G1 & G2 & G3 & G4 & G5 \\
\hline $\begin{array}{c}\text { Reference } \\
\text { Oxides }\end{array}$ & Okamoto, et al. [8] & $\begin{array}{l}\text { Okamoto, et } \\
\quad \text { al. }[8]\end{array}$ & Araújo et al. [9] & $\begin{array}{c}\text { Arcaro, et al. } \\
\text { [7] }\end{array}$ & $\begin{array}{l}\text { Datta and Das } \\
\text { (ARDB-3) [6] }\end{array}$ \\
\hline Glass type & Borossilicate & Borossilicate & Borossilicate & Soda lime & $\begin{array}{l}\text { Aluminium- } \\
\text { borosilicate }\end{array}$ \\
\hline $\mathrm{Al}_{2} \mathrm{O}_{3}$ & - & 2.96 & 2 & - & 15 \\
\hline $\mathrm{SiO}_{2}$ & 78.99 & 80.66 & 81 & 68.08 & 45 \\
\hline $\mathrm{B}_{2} \mathrm{O}_{3}$ & 19.04 & 12.48 & 13 & - & 35 \\
\hline $\mathrm{K}_{2} \mathrm{O}$ & 1.97 & - & - & 9.56 & - \\
\hline $\mathrm{Na}_{2} \mathrm{O}$ & - & 3.9 & 3.5 & 22.36 & - \\
\hline $\mathrm{Li}_{2} \mathrm{O}$ & - & - & - & - & - \\
\hline $\mathrm{ZrO}_{2}$ & - & - & - & - & 2.5 \\
\hline $\mathrm{ZnO}$ & - & - & - & & 2.5 \\
\hline
\end{tabular}

Powder compositions alumina (High Purity Alumina > 99\%, $\leq 150 \mathrm{~nm}$, TM-DAR, Taimei, Japan) containing $5 \mathrm{wt} . \%$ glass were blended in ethanol in a ball mill using zirconia balls for $2 \mathrm{~h}$ at $600 \mathrm{rpm}$. After mix- 
ing, the powder compositions were dried at $100^{\circ} \mathrm{C}$ for $24 \mathrm{~h}$ in an oven. The resulting mixes were granulated through a 200 mesh continuous vibration screen for $50 \mathrm{~min}$. Then, prismatic blocks (4 $\mathrm{mm}$ x $4 \mathrm{~mm}$ x $4.7 \mathrm{~mm}$ ) were compacted via dry uniaxial pressing at $30 \mathrm{MPa}$ followed by cold isotactic pressing at $200 \mathrm{MPa}$.

Thermal expansion behavior of the samples was investigated trough dilatometry (Netzsch DIL 402 PC), with heating rate of $1{ }^{\circ} \mathrm{C} / \mathrm{min}$ up to $1200^{\circ} \mathrm{C}$, hold time of $5 \mathrm{~h}$, and cooling rate of $1{ }^{\circ} \mathrm{C} / \mathrm{min}$ down to room temperature. The green bodies were then sintered in an air oven (HT Nabertherm D 2804) with a constant heating/cooling rate $5^{\circ} \mathrm{C} / \mathrm{min}$ with hold at $1200^{\circ} \mathrm{C}$ for $60 \mathrm{~min}$.

The morphology of the samples was obtained by scanning electron microscopy (Zeiss Supra 55VP FEG-SEM) of the alumina with additives samples after sintering.

Apparent density measurements of the sintered samples were performed using the Archimedes principle [13] using distilled water as the immersion liquid. The respective specific theoretical densities of the oxides used in this work were those provided by the manufactures. The hardness of the samples was determined using the Vickers technique, with load of $1 \mathrm{kgf}$ for $30 \mathrm{~s}$ in each indentation [14], in a dedicated equipment (Zwick 3212).

The powders (G1P, G2P, G3P, G4P and G5P) and sintered samples (G1S, G2S, G3S, G4S and G5S) were analyzed by X-ray diffraction (XRD, Bruker AXS D8 Discover), using CuK $\alpha$ radiation, $40 \mathrm{kV}$ and 40 $\mathrm{mA}$, in the range of $2 \theta$ between $20^{\circ}$ and $80^{\circ}$.

\section{RESULTS AND DISCUSSION}

\subsection{Sintering Behavior, densification and mechanical performance}

Figure 1 shows the linear shrinkage (LS) plots of the alumina/glass compositions compared to pure alumina. Sintering occurs in the range of $1050^{\circ} \mathrm{C}$ to $1100^{\circ} \mathrm{C}$ in the case of the glass containing ceramics. These temperatures are considerably low when compared to submicron pure alumina, which usually sinters in the of in the range of $1300^{\circ} \mathrm{C}$ to $1500^{\circ} \mathrm{C}$ [15].

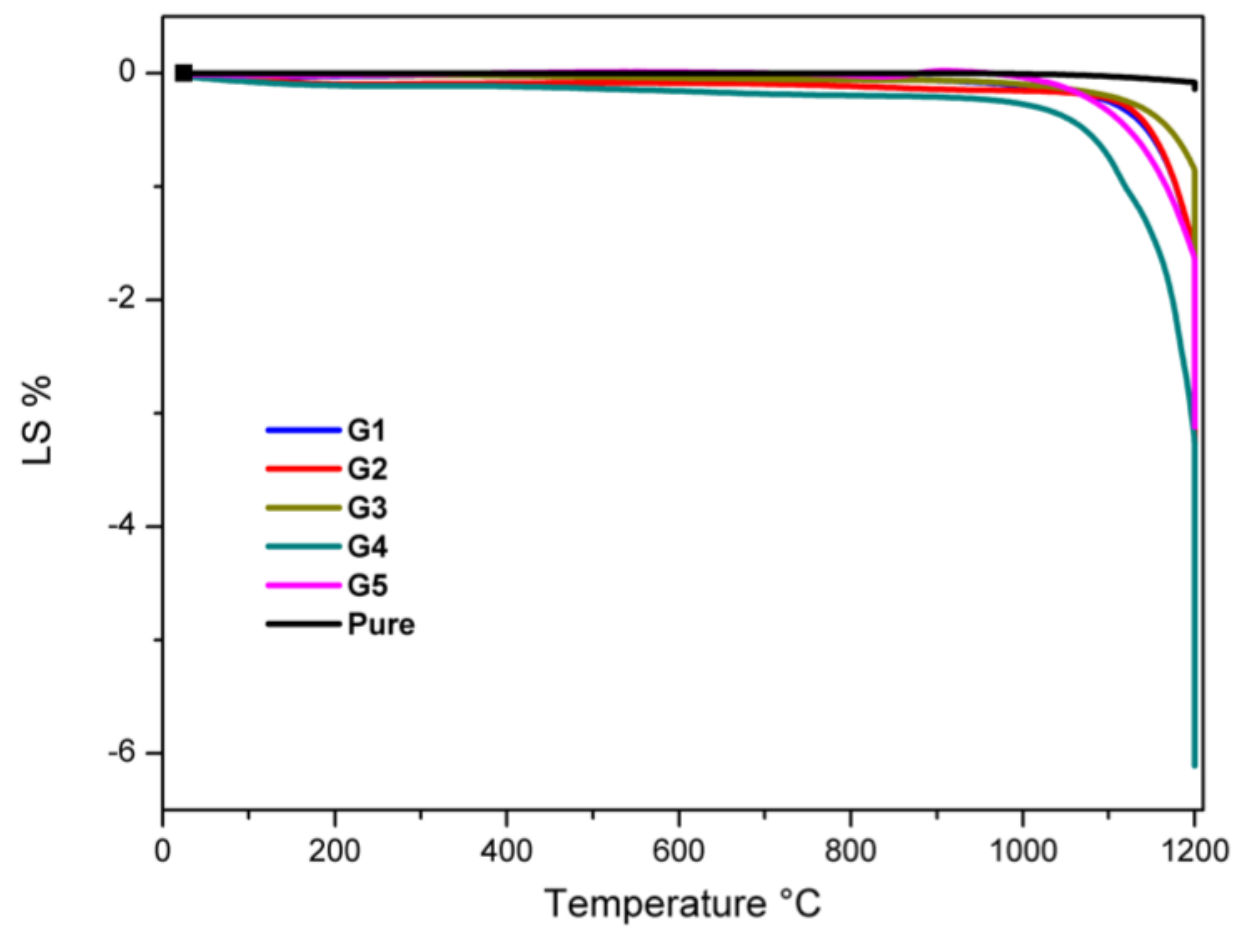

Figure 1: Linear shrinkage (LS) of the ceramic glass matrix compositions.

It was observed that compositions G2, G3 and G4 presented lower sintering temperatures, $1075^{\circ} \mathrm{C}$, $1075^{\circ} \mathrm{C}$ and $1050^{\circ} \mathrm{C}$, respectively. This was related to a similar composition of G2 and G3, both containing $3.5-3.9 \% \mathrm{Na}_{2} \mathrm{O}$ in the precursor glass, which is a well-known fluxing agent. In the case of composition G4, 
which is based on soda lime glass, the content of $\mathrm{Na}_{2} \mathrm{O}$ in the soda lime glass is much higher $(\sim 22 \%)$, so that it forms a liquid phase at the lowest temperature.

For composition $\mathrm{G} 1$, which contains $\mathrm{K}_{2} \mathrm{O}$, sintering started at about $1100^{\circ} \mathrm{C}$. In this case, $\mathrm{K}_{2} \mathrm{O}$ present in the precursor glass (G1) is slightly less active as a flux when compared to $\mathrm{Na}_{2} \mathrm{O}$ (used in G2 and G3 for example). Alkaline oxide act as modifiers connecting through ionic bounds to anions network and such ions act breaking covalent bonds, as in the case of $\mathrm{Si}-\mathrm{O}-\mathrm{Si}$, thereby causing the onset of oxygen atoms unbound in silica-based materials [16-17].

Thus, the addition of fluxing aids, in special Na-based, break the links between bridges of polyhedrons $\left(\mathrm{SiO}_{4}\right)$ forming a terminal anion which neutralizes the charge of cation, positioned in the interstices of the three-dimensional structure, causing a strong flux that is slightly stronger than K-based aids [18].

The Figure 2 illustrates the values of relative density and Vickers hardness in function of the compositions studied.

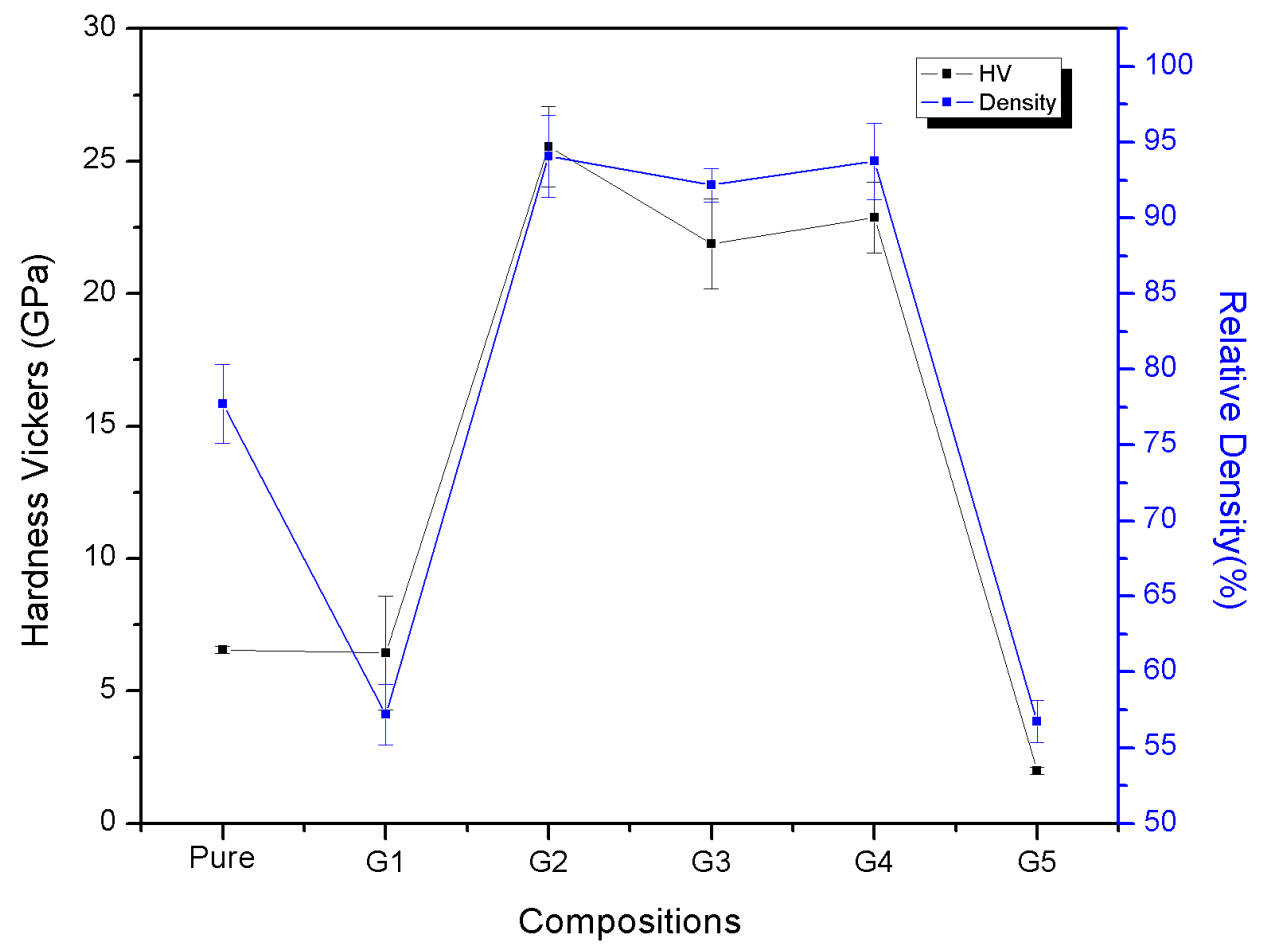

Figure 2: Relative density compared hardness Vickers values of alumina/glass sintered at $1200^{\circ} \mathrm{C}$.

For G4 and G2, the density values were around 95\%, and for the G3 curves, the density presented a value above $90 \%$. Similar results were found by Montedo et al. 2017 [19], who studied the effects of a glass ceramic LZSA $\left(11.6 \mathrm{Li}_{2} \mathrm{O} \quad 16.8 \mathrm{ZrO}_{2} 68.2 \mathrm{SiO}_{2} 3.4 \mathrm{Al}_{2} \mathrm{O}_{3}\right)$ in the sintering behavior of the alumina obtained by phase sintering.

The authors showed that the glass ceramic increased the densification of the alumina studied, but one of the samples reached a relative density of $95 \%$ in the sintered samples at $1600^{\circ} \mathrm{C} / 40$ min compared to $85 \%$ for the sintered at $1600^{\circ} \mathrm{C} / 4 \mathrm{~h}$, being a potential candidate to improve the densification of alumina in applications where wear resistance is the primary requirement.

The additives used in G1 and G5 have a strong influence on the hardness and the density of the samples presenting lower values in relation to the other compositions. The alpha alumina exhibits a hexagonal corundum structure. In this structure, the $\mathrm{Al}^{3+}$ cations occupy only two-thirds of the available sites and an idle interstitial site arises between alternating $\mathrm{Al}^{3+}$ pairs. The capture of the alumina filler may occur around defects resulting from the dissolution of impurities (i.e. doping cations and their charge compensation defects). In sintered materials, it is also necessary to consider the effect of grain contours, segregation of impurities and defects in the interfaces [20]. These dopant atoms may have contributed to the formation of punctual 
defects, thus increasing the concentration of native defects in the crystal, which may hinder the sintering kinetics, generating a high porosity for samples G1 and G5.

The porosity produces adverse effects on the mechanical properties, since the existence of pores can result in the reduction of hardness. When there is a decrease in the pores, the penetrator is more difficult to retreat into fully dense regions.

\subsection{Structural and microstructural analysis}

Alumina $(\alpha)$ is in JCPDS (COD 90077496) and quartz in JCPDS (COD 9006307) were identified in all samples. In general, the appearance of the andalusite $\left(\mathrm{Al}_{2} \mathrm{SiO}_{5}\right)$ phase in JCPDS (COD 9000919). It is possible to verify that the peaks referring to all the phases in the powder samples intensify with the sintering. The Figure 3 shows the XRD results of the powdered samples and for the sintered specimens.

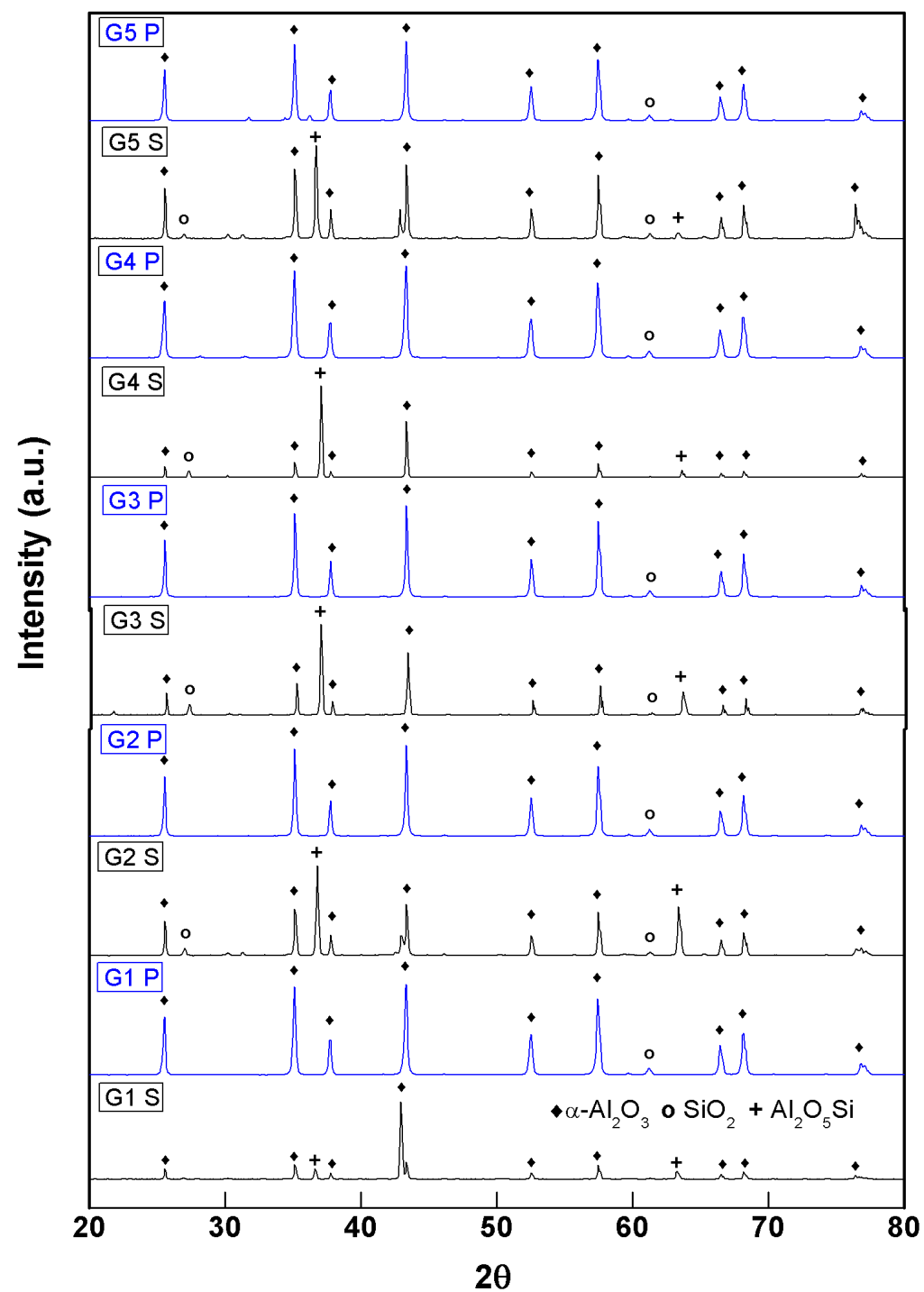

Figure 3: XRD patterns of samples prepared from milled powders and the sintered samples at $1200^{\circ} \mathrm{C}$.

\subsection{SEM}

The morphological aspects of the sintered samples were observed in Figure 4. It is possible to observe that samples G1 (a) and G5 (d) exhibited an irregular morphology with the presence of intergranular porosity. For G5, it was observed the formation of necks between the particles and a decrease of the voids, which was related to the beginning of sintering. In contrast, the G2 (b) and (G4) composition had higher densification, as 
can be seen in the dilatometric curves and in the density plot. The same morphological aspect was observed for the G3 composition, with similar densification to the G2 composition.
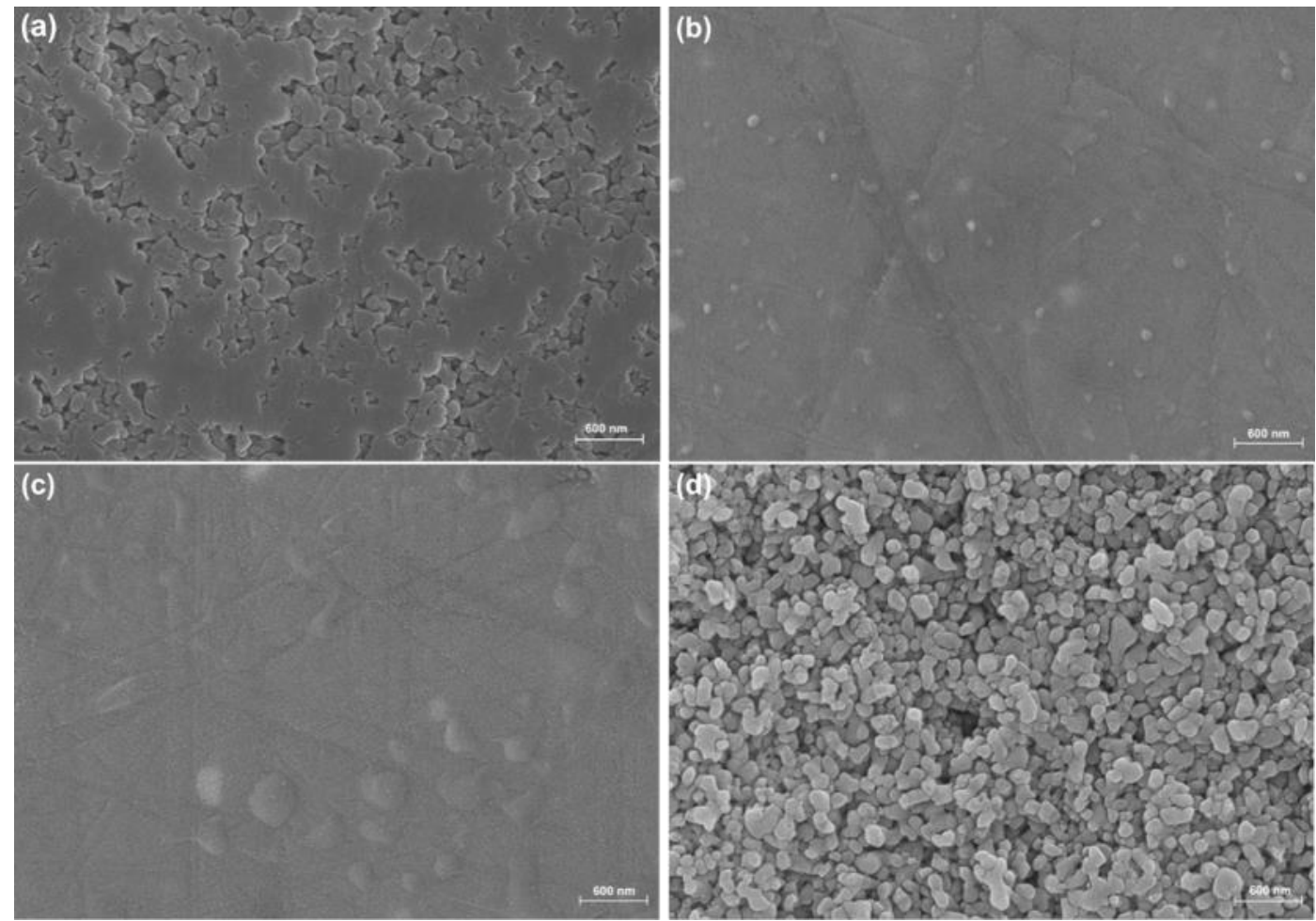

Figure 4: Representative scanning electron micrograph of the sintered samples (a) G1, (b) G2, (c) G4 and (d) G5 (50.000 $\times$ magnification).

\section{CONCLUSION}

Alumina/glass systems were formulated, processed and thermally treated in order to reduce the sintering temperature as well as to improve microstructural characteristics. According to the SEM images, it was possible to observe an irregular morphology with the presence of intergranular porosity for samples G1 and G5. Samples G2, G3, and G4 were denser and more uniform. Glass used as sintering aids were effective in lowering the alumina sintering temperature. However, for the compositions G1 and G5 an increase of porosity was observed, which influenced the mechanical properties.

\section{ACKNOWLEDGEMENTS}

The Cooperation Program PROBRAL/CAPES/DAAD is acknowledged for the financial support.

\section{BIBLIOGRAPHY}

[1] ARCARO, S., NIETO, M., MORENO, R., et al., "The influence of nano alumina additions on the coefficient of thermal expansion of a LZS glass-ceramic composition", Ceramics International, v. 42, n.7, pp. 8620-8626, 2016.

[2] MINATTO, F.D., MILAK, P., DE NONI, A., et al., "Multilayered ceramic composites-a review", Advances in Applied Ceramics, v. 114, n.3, pp. 127-138, 2015.

[3] CESCONETO, F., ARCARO, S., RAUPP-PEREIRA, F., et al., "TiO 2 nanoparticulated LZSA glassceramic matrix composites", Ceramics International, v. 40, n.7, pp. 9535-9540, 2014.

[4] CAMARGO, P.H.C., SATYANARAYANA, K.G., WYPYCH, F., "Nanocomposites: synthesis, structure, properties and new application opportunities”, Materials Research, v. 12, n.1, pp. 1-39, 2009. 
[5] DE LA IGLESIA, P., GARCÍA-MORENO, O., MENÉNDEZ, J., et al., "Microstructural development and mechanical performance of mullite-alumina and hibonite-alumina ceramics with controlled addition of a glass phase", Ceramics International, v. 44, n.2, pp. 2292-2299, 2018.

[6] DATTA, S., DAS, S., "A new high temperature resistant glass ceramic coating for gas turbine engine components", Bulletin of Materials Science, v. 28, n.7, pp. 689-696, 2005.

[7] ARCARO, S., NIETO, M. I., RODRIGUES NETO, J.B., et al., " $\mathrm{Al}_{2} \mathrm{O}_{3}$ nanoparticulate LSZ glassceramic matrix composites for production of multilayered materials", Journal of the American Ceramic Society, v. 99 (11), pp. 3573-3580, 2016.

[8] OKAMOTO, M., TANEI, H., IWANAGA, S., et al., "Borosilicate glasses with high softening points for glass-ceramic/copper multilayer substrates", Journal of the Ceramic Society of Japan, v. 116, n.1352, pp. 561-565, 2008.

[9] ARAUJO, P.F., DAROS, L.B., SOUZA, M., et al., "Influence of sintering conditions on the microstructure and properties of alumina-filled borosilicate glass", Journal of the Ceramic Science and Technology, v. 7, n.1, pp. 119-126, 2016.

[10] LIMA, M., MONTEIRO, R., GRAÇA, M., DA SILVA, M.F., "Structural, electrical and thermal properties of borosilicate glass-alumina composites", Journal of Alloys and Compounds, v. 538, pp. 66-72, 2012.

[11] EL-KHESHEN, A., ZAWRAH, M., "Sinterability, microstructure and properties of glass/ceramic composites", Ceramics international, v. 29, n.3, pp. 251-257, 2003.

[12] RODRIGUES, P.L., DE ALMEIDA, F.S., MOTISUKE, M., DE SOUSA, E., "Effect of alumina addition on the physical and mechanical properties of tricalcium phosphate", Cerâmica, v. 58, n.347, pp. 368-373, 2012.

[13] SHAHRAKI, A., GHASEMI-KAHRIZSANGI, S., NEMATI, A., "Performance improvement of MgO$\mathrm{CaO}$ refractories by the addition of nanosized $\mathrm{Al}_{2} \mathrm{O}_{3}$ ", Materials Chemistry and Physics, v. 198, pp. 354-359, 2017.

[14] SEABAUGH, M. M., KERSCHT, I. H., MESSING, G. L., "Texture development by templated grain growth in liquid-phase-sintered $\alpha$-alumina", Journal of the American Ceramic Society, v. 80 (5), pp. 1181$1188,1997$.

[15] MA, J., LIM, L.C., "Effect of particle size distribution on sintering of agglomerate free submicron alumina powder compacts", Journal of the European Ceramic Society, v. 22, n.13, pp. 2197-2208, 2002.

[16] LIU, M., ZHOU, H. Q., ZHU, H. K., et al., "Microstructure and dielectric properties of Ca-Al-B-Si-O glass $/ \mathrm{Al}_{2} \mathrm{O}_{3}$ composites with various alkali oxides contents", Journal of Central South University, v. 19, n.10, pp. 2733-2739, 2012.

[17] ZHAO, L. H., WEI, W., BAI, H., et al., "Synthesis of steel slag ceramics: chemical composition and crystalline phases of raw materials", International Journal of Minerals, Metallurgy, and Materials, v. 22, n.3, pp. 325-333, 2015.

[18] FANG, Y.C., JEAN, J.H., "Effects of alumina on densification of a low-temperature cofired crystallizable glass+ alumina system", Japanese journal of applied physics, v. 46, 6A, pp. 3475, 2007.

[19] MONTEDO, O.R.K., MILAK, P.C., FALLER, C.A., et al., "Effect of LZSA glass-ceramic addition on pressureless sintered alumina. Part I: Grain growth", Materials Research, v. 20, pp. 1024-1028, 2017.

[20] KAMEL, Z., GÉRARD, M., ABDERRAHMANE, S.A., et al., "Effects of the microstructure induced by sintering on the dielectric properties of alumina", In: Sintering of Ceramics-New Emerging Techniques, InTech, 2012.

\section{ORCID}

Larissa Bezerra da Silva Diego Blaese

Ana Paula da Silva Peres

Antonio Carlos Silva da Costa Wilson Acchar https://orcid.org/0000-0002-1617-5425

https://orcid.org/0000-0002-3549-582X

https://orcid.org/0000-0002-1323-9059

https://orcid.org/ 0000-0001-5229-8492

https://orcid.org/0000-0002-5585-1799 